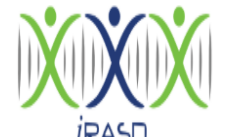

iRASD

Volume 9, Number 3, 2021, Pages 259-264

SCIENCES (PJHSS)

Journal Homepage:

https://journals. internationalrasd.org/index.php/pjhss

\title{
An Evaluation of Communicative Language Teaching in Pakistan: A Study of Undergraduate English Learners of Pakistan
}

\author{
Aila Noor ${ }^{1}$, Amna Shahid ${ }^{2}$, Shehzad Ahmed ${ }^{3}$, Minaa Ahmad ${ }^{4}$ \\ ${ }^{1}$ Applied Linguistics Department Kinnaird College for women Lahore, Pakistan. Email: nooralia392@gmail.com \\ ${ }^{2}$ Lecturer, Applied Linguistics Department Kinnaird College for women Lahore, Pakistan. \\ Email: mna.shahid@kinnaird.edu.pk \\ ${ }^{3}$ Assistant Professor, Faculty of Education, University of Okara, Pakistan. Email: dr.shehzad@uo.edu.pk \\ ${ }^{4}$ Applied Linguistics Department Kinnaird College for women Lahore, Pakistan. Email: minnaa.ahmad90@gmail.com
}

\begin{tabular}{|c|c|}
\hline \multicolumn{2}{|l|}{ Article History: } \\
\hline Received: & October 13,2021 \\
\hline Revised: & November 10,2021 \\
\hline Accepted: & November 14, 2021 \\
\hline Available Online: & November 15,2021 \\
\hline \multicolumn{2}{|c|}{ Keywords: } \\
\hline \multirow{3}{*}{\multicolumn{2}{|c|}{$\begin{array}{l}\text { Communicative Language Teaching } \\
\text { Classroom Activities } \\
\text { Communicative Competence }\end{array}$}} \\
\hline & \\
\hline & \\
\hline Fluency & \\
\hline Accuracy & \\
\hline
\end{tabular}

\section{ABSTRACT}

The research was focused on the use of communicative method of teaching. Through the use of such an advanced approach, students are unable to be considered as proficient speakers of English language. Various factors were highlighted in this research that cause a hindrance in the success of communicative method teaching. It was also identified how this approach can have positive effects on the students that would help them become proficient speakers of English language (Nazir, Abbas, \& Naz, 2020). 5-point Likert scale was used in the questionnaires that were filled by 100 students of only one private sector in Lahore. The results deducted the positive effects of this approach along with the reasons of its inability to produce proficient speakers and how it can be sorted out.

(C) 2021 The Authors, Published by iRASD. This is an Open Access Article under the Creative Common Attribution Non-Commercial 4.0

Corresponding Author's Email: nooraila392@gmail.com

\section{Introduction}

It is through the real meaning that learning takes place through effective language which is the basis of the method of communication. No matter how much experience in teaching you have, sometimes you are unable to find out which strategy goes best for the students.

"Communicative Language Teaching" means different things for different teachers. The word means other things. For certain teachers, this implies that greater focus is placed on using the target language in schools, particularly on orality. Communicative Language Teaching (CLT) emphasizes contact as the medium and primary aim of language acquisition, which is an approach to teaching second languages and foreign languages (Chohan, Abbas, \& Saleem, 2018). The 'Communication Approach', also known as the CLT, has always been regarded as an ALM response and a notional functional syllabus extension and growth. With the more recent refinement of CLT, task-based language learning has become much more common. Communicative language teaching (CLT) stresses communication as a medium and as the main objective of language education, a multilingual and international language teaching method. CLT has traditionally been regarded as an expansion or improvement of the Notional Practical Syllabus in response to the Audio-Lingual System (ALM). The new refinement of CLT, working-based language learning, has been an enormous success. Communication in the communication language can be understood as a collection of rules concerning language learning purposes, how students master the language, the kinds of educational experiences that help them learn the most, and the roles of teachers and students in the classroom. The following facets of language knowledge require communication skills: Knowing how to use language for several functions; - Knowing how to vary our linguistic use by the context and the participants; - Knowing how to create and interpret various forms of texts. Communication is also a way to teach foreign languages and stresses communication as a means and primary language learning goal. 
The significance of this study is to recognize the reasons that why there are no proficient speakers of English language even after the use of communicative teaching method. The intrinsic and extrinsic factors of students are to be observed. As the students are instilled with various skills, they are unable to keep pace with fluency and accuracy. It has to be known as to why students are unable to communicate well in English language if communicative language teaching approach is successfully utilized in classroom. It must also be known if this strategy used in Pakistan is a suitable approach for teaching. If all the factors will be revealed, efforts can be made to finish them so that students face no trouble in speaking the targeted language proficiently. Focus has to be on accuracy too along with fluency and that is only possible if the problems in the approach communicative language teaching are identified. The purpose of the study is to show how a teacher just not has to be an instructor but a facilitator as well. It is through this approach that all four necessary skills of English language are integrated among students, therefore some good research is mandatory.

This study is significant in highlighting the reasons behind communicative language teaching not being able to produce proficient speakers of English language despite its own success. It would help us to know whether this approach is a good choice for teaching the second language in class and if yes, then how is this approach being applied in classroom environment and what affects does it have on students. The present study will:

- Explore the impact of communicative language teaching at undergraduate level

- Analyse the use of communicative approach in classroom

- Evaluate the influence of communicative approach of teaching on speaking skills

The research questions are as follows;

- Does communicative language teaching have positive impact in producing proficient speakers of English?

- Are any factors causing hindrance in the success of this approach?

- Is classroom environment a barrier in the success of CLT approach?

Despite the ardent use of communicative method approach, students are unable speak English language proficiently. The focus of this study is limited to the students enrolled in the undergraduate programme in a private sector of one city of Pakistan. It is limited to those students who are being taught via the communicative language teaching approach. This involves the undergraduate students of Kinnaird college for women, Lahore, Pakistan. The study is limited by the following:

- The participant students consist of only females as due to covid-19, other sectors did not allow performing research in their area

- The study is restricted to find effects of CLT and the hindrance factors within the classroom.

\section{Literature Review}

Communicative language teaching was introduced in 1970s which follows a theory that communication is the primary function of the language. Since the inception of CLT, it is considered to be the most sophisticated and prevailing approach which focuses on developing the communicative competence of the students by involving them in the real-life situations where they can interact very well with each other and the instructor (Bhatti, Abbas, \& Rana, 2020). In 2018, Bao E Sang conducted a study in China on the efficacy of CLT. It has been prevalent among academic and professional researchers since China introduced the Communicative Language Teaching (CLT) programme. In 2015, Wen wen carried out a report. In this research, CLT results in the integrated English translation stage were studied to determine whether L1 is to be used in a timely fashion in the CLT class and whether students improved their learning conditions after two round trip surveys (AR). A case analysis on Pakistan by Saeed Ahmad was carried out in 2013. The first part is a longitudinal study to investigate the comparative Advantages of English grammar and communicative language developing test severable, which, after assessment, is used to assess students' achievement and behaviour. In the second part of the report, we study Pakistani teachers on the second 
higher-level approach and impediments to the understanding of CLT. Another research was performed by Fang An-Ju in 2013 in China, where he critically analyzed Communicative language teaching. He made an evaluation that the complete review of history, theory and application is the basis of this theory. He also discussed some of the problems involved in this approach like the cultural conflicts, the training of the teachers etc. Taking account of the diverse collections of CLT values proposed by many scholars, the following principles can be summarized:

- Grammar place / significance.

- Mission and tasks for the group/pair.

- Error correction quality and quantity.

- Teacher's role in the lessons.

- Learning the role and needs of students.

\section{Methodology}

\subsection{Nature of Research}

The research type is a quantitative approach achieved through a 5-point-likert scale with closed ended questions. The research aimed to find how the communicative approach of teaching is being used in classrooms. This meant to deduct the effects of this strategy and how despite its benefits, it is unable to produce proficient speakers of English language.

\subsection{Population}

The research comprised of regular students of undergraduate department at Kinnaird college for women.

\subsection{Sample Size}

There were close ended questions for 100 students. A sample of 100 students was selected from Kinnaird college for women.

\subsection{Research Tools}

The tools used in this study were the questionnaires. The questionnaires were designed in a way that it would meet the main objective of the study which was to find and determine why communicative teaching approach is not able to produce proficient speakers of English language and what barriers cause a hindrance in its success. Google document was used to make the questionnaire and for its online filling.

\subsection{Reliability and Validity}

Questionnaires were checked by the supervisor to clarify the reliability. Validity of questionnaire was made sure by keeping the questions appropriate and relevant to the topic. All the relevant aspects of the research were covered in the questionnaire and it was made compulsory in every question to completely avoid the personal benefits of the researcher.

\section{Data Analysis}

The results are consistent with the findings of Ngoc and Iwashita (2012), who examined the attitudes of Vietnamese students and teachers towards Communicative Language Teaching (CLT) in general and each of the four CLT-related factors such as instruction in grammar, correction of errors, workplaces between the two groups and the position of teachers. In their analysis they concluded that learners were more favourable than the other CLT rules to the position of pairs/groups function, but were less favourable to the grammar education.

The findings of a more comprehensive study show that the bulk of the teachers in high school comply with all five CLT principles and respect them. Furthermore, the teachers had the best outlook towards "group/pair-work and activity tasks;" the less desirable is, however, "quality and amount of error correction" as well as "situation and value of grammar." The research has helped Rahimi and Naderi (2014), who have assessed the attitude of EFL teachers towards CLT and the issues they have in their classes with the implementation of this process. The results based on the results of the interview of previous studies were confirmed and checked with the results obtained in the current study through the students' survey. Based on the findings of semi-structured polls, the majority of students agreed in general with CLT that this methodology enhances students' communication skills as well as their grammatical 
awareness in comparison to their previous approach (GTM). Furthermore, all five values of CLT were decided by the majority of participants.

Table 1

\begin{tabular}{|c|c|c|c|c|c|c|}
\hline Sr. & Questions & $\begin{array}{l}\text { Strongly } \\
\text { Disagree }\end{array}$ & Disagree & Neutral & Agree & $\begin{array}{c}\text { Strongly } \\
\text { agree }\end{array}$ \\
\hline 1 & $\begin{array}{l}\text { Do you feel hesitant in interacting } \\
\text { with people outside classroom? } \\
\text { Does interaction in classroom }\end{array}$ & 11 & 28 & 32 & 24 & 5 \\
\hline 2 & $\begin{array}{l}\text { increase when involved in group } \\
\text { activities? }\end{array}$ & 3 & 3 & 10 & 51 & 33 \\
\hline 3 & $\begin{array}{l}\text { Do classroom activities assess your } \\
\text { language needs properly? } \\
\text { Do the assessment tasks in }\end{array}$ & 1 & 11 & 33 & 46 & 9 \\
\hline 4 & $\begin{array}{l}\text { classroom make a positive } \\
\text { contribution to your language } \\
\text { learning? }\end{array}$ & 1 & 10 & 17 & 57 & 15 \\
\hline 5 & $\begin{array}{l}\text { Do the learning resources in } \\
\text { classroom promote better } \\
\text { understanding of the language? }\end{array}$ & 2 & 8 & 15 & 58 & 17 \\
\hline 6 & $\begin{array}{l}\text { in classroom for understanding the } \\
\text { language better? }\end{array}$ & 2 & 2 & 20 & 51 & 25 \\
\hline 8 & $\begin{array}{l}\text { have better control over learning the } \\
\text { language? }\end{array}$ & 2 & 4 & 22 & 52 & 20 \\
\hline 9 & $\begin{array}{l}\text { Does team work in classroom help } \\
\text { you in better language practice? } \\
\text { Do you perceive improvement in }\end{array}$ & 2 & 1 & 19 & 54 & 24 \\
\hline 10 & $\begin{array}{l}\text { your level of English through } \\
\text { classroom activities? }\end{array}$ & 2 & 3 & 25 & 47 & 23 \\
\hline 11 & $\begin{array}{l}\text { Does student centered method make } \\
\text { you comfortable? }\end{array}$ & 5 & 12 & 32 & 42 & 9 \\
\hline 12 & $\begin{array}{l}\text { Do you think fluency is better than } \\
\text { accuracy in speech? }\end{array}$ & 12 & 32 & 21 & 28 & 7 \\
\hline 13 & $\begin{array}{l}\text { Do you find your speaking skills } \\
\text { satisfactory? } \\
\text { Does large class size create problem }\end{array}$ & 2 & 12 & 36 & 43 & 7 \\
\hline 14 & $\begin{array}{l}\text { for you to interact with your } \\
\text { instructor? }\end{array}$ & 2 & 7 & 20 & 50 & 21 \\
\hline 15 & $\begin{array}{l}\text { Does negative feedback from } \\
\text { teacher's side decrease your } \\
\text { motivation in classroom? }\end{array}$ & 3 & 7 & 20 & 38 & 32 \\
\hline 16 & $\begin{array}{l}\text { In your opinion, do grammatical } \\
\text { rules help in being fluent in English? } \\
\text { Does trial and error during classroom }\end{array}$ & 5 & 18 & 32 & 28 & 17 \\
\hline 17 & $\begin{array}{l}\text { discussion improve speech } \\
\text { production? }\end{array}$ & 1 & 7 & 21 & 50 & 21 \\
\hline 18 & $\begin{array}{l}\text { Do communicative activities promote } \\
\text { better speaking skills? }\end{array}$ & 5 & 0 & 19 & 53 & 23 \\
\hline 19 & $\begin{array}{l}\text { Does positive feedback in classroom } \\
\text { develop communicative competence? } \\
\text { Does the use of language increase }\end{array}$ & 2 & 2 & 12 & 53 & 31 \\
\hline 20 & $\begin{array}{l}\text { proficiency more than the knowledge } \\
\text { of language? }\end{array}$ & 2 & 5 & 20 & 45 & 28 \\
\hline
\end{tabular}

Keeping in view the research questions, we had to find out if communicative language teaching had a positive effect in producing proficient speakers of English language. So far, we know that this approach promotes communication and interaction among people which is a great way to polish the speaking skills of the students. Although through the survey, no negative impacts were discovered but still it was known that students are not able to communicate proficiently. That is because of a certain number of factors that overcome this 
approach. Some of those factors explored in this study include the large size of the classroom where students feel hesitant in communicating with the teachers and their queries go unanswered. Similarly, another factor is the negative feedback received from the teachers that demotivates the students and they believe they are incapable of doing something. They then do not make any more effort in trying to improve themselves. Additionally, the inability of students to use grammatical rules in creating a proper sentence causes a hindrance in their way of speaking English language proficiently. The focus on fluency instead of accuracy is a great trouble when they want to be called proficient speakers of English language. As we discovered the factors that explain why this approach is unable to produce proficient speakers, we also had to investigate whether this approach was good enough or suitable for students or not. According to the majority of students, they can be present better communication skills when involved in group activities. They believe the needs of their language can be assessed properly through the activities scheduled to take place in class. This also requires constant communication between students and instructors as the understanding of language is enhanced. It all points out that the method is somehow focused on students which make them comfortable enough to focus on the language and acquire it accurately. All the pointers hint towards the requirements in communicative language teaching which shows that the approach is very well designed and suitable for classroom. The only problem is the discovered factors that cause a hindrance in its way of producing proficient speakers of English language.

\section{Conclusion}

The findings of this research have concluded that communicative language teaching is completely suitable and perfect strategy to be applied in classrooms when teaching second or foreign language. Due to certain factors, it is unable to produce proficient speakers of English language. Some students hold the view that their speaking skills are satisfactory and they remain unaffected by the factors that hinder the production of proficient speakers. While most of the students are not happy with their speaking abilities and completely agree with the fact that some reasons are a great hurdle in their way of acquiring the language proficiently. Also, a very low number of people prefer fluency over accuracy and majority believe that accuracy is more important as compared to fluency. That is why communicative method approach is better as it promotes interaction among students and teachers. Although it is great success in other countries, improvements are needed for it to work more efficiently in Pakistan. The research also observed that the use of language itself is better to improve the speaking skills of students. Simple knowledge about language may not be as helpful as using it in practice. Another great way of involving all students in communication is through group activities where they can portray their abilities better. The research deducted how the inability of students to speak English language proficiently is also somehow the fault of teachers. Some actions cause students to feel demotivated and they stop their attempts to speak the targeted language accurately and properly. The research concluded that basically large class size, negative feedback from teacher's side, trial and error process, etc. overshadow the hard work of students when trying to speak the targeted language proficiently.

\section{References}

Abbas, F., Aslam, S., \& Khan, R. A. M. (2011). Code-mixing as a communicative strategy among the university level students in Pakistan, Language in India, 11 (1), 95-108.

Abbas, F., Rana, A. M. K., Bashir, I., \& Bhatti, A. M. (2021). The English language proficiency as a global employment skill: the viewpoint of Pakistani academia. Humanities and Social Sciences Review. 9 (3), 1071-1077.

Alamri, W. (2018). Communicative Language Teaching: Possible Alternative Approaches to CLT and Teaching Contexts. English Language Teaching, 11(10), 132. https://doi.org/10.5539/elt.v11n10p132

Bhatti, A. M., Abbas, F., \& Rana, A. M. K. (2020). An Empirical study of learning styles used by undergraduate English learners in public sector colleges in Pakistan. Elementary Education Online, 19(3), 1864-1875.

Boucher, A. (1991). Mitchell, Rosamond. Communicative Language Teaching in Practice. London: Centre for Information on Language Teaching and Research, 1988Mitchell, Rosamond. Communicative Language Teaching in Practice. London: Centre for Information on Language Teaching and Research, 1988. Pp. 188. Canadian Modern Language Review, 47(3), 545-546. https://doi.org/10.3138/cmlr.47.3.545 
Chohan, M. N., Abbas, F., \& Saleem, M. (2018). CALL as a tool in teaching EFL in Pakistani religious institutes (Madaris): A survey of issues and challenges. Al Qalam, 23(1), 355368.

Hoque, M., Idrus, R., \& Islam, Y. (2018). A Health-Check of Communicative Language Teaching (CLT) in Rural Primary Schools of Bangladesh. English Language Teaching, 11(7), 163. https://doi.org/10.5539/elt.v11n7p163

Ju, F. (2013). Communicative Language Teaching (CLT): A Critical and Comparative Perspective. Theory And Practice In Language Studies, 3(9), 58. https://doi.org/10.4304/tpls.3.9.1579-1583

Kasumi, H., 2015. Communicative Language Teaching and Its Impact on Students' Performance. Journal of Educational and Social Research, [online] 5(1), p.9. Available at: <https://www.researchgate.net/publication/276459978>.

Light, T., \& Littlewood, W. (1982). Communicative Language Teaching: An Introduction. Language, 58(4), 952. https://doi.org/10.2307/413984

Molla, N. (2019). Communicative Language Teaching (CLT) Approach Towards Speaking Ability. English Focus: Journal Of English Language Education, 2(1), 10-24. https://doi.org/10.24905/efj.v2i1.50

Nazir, S., Abbas, F., \& Naz, F. (2020). Historical development of orthography in English and impact of computer-mediated communication (CMC) on the emerging orthographic patterns in English. PalArch's Journal of Archaeology of Egypt/Egyptology, 17(11), 162175.

Nguyen, C., \& Le, D. (2020). Communicative Language Teaching: Do Tasks and Activities in School Textbooks Facilitate Learners' Development of Communicative Competence?. Journal Of Language Teaching And Research, 11(5), 688. https://doi.org/10.17507/jltr.1105.04

Rahmatillah, K. (2019). Communicative Language Teaching (CLT) through Role Play and TaskBased Instruction. Script Journal: Journal Of Linguistic And English Teaching, 4(2), 161. https://doi.org/10.24903/sj.v4i2.339

Shah Jabeen, S. (2014). Implementation of Communicative Approach. English Language Teaching, 7(8), 24. https://doi.org/10.5539/elt.v7n8p68

Sung, K. (2010). Promoting Communicative Language Learning through Communicative Tasks. Journal Of Language Teaching And Research, 1(5). https://doi.org/10.4304/jltr.1.5.704-713

Tayebinik, M., Tizjang, E., \& Najarian, S. (2018). Communicative Language Teaching (CLT) method in Iran. International Academic Journal Of Humanities, 05(02), 58-65. https://doi.org/10.9756/iajh/v5i2/1810026

Wu, W. (2008). Misunderstandings of Communicative Language Teaching. English Language Teaching, 1(1). https://doi.org/10.5539/elt.v1n1p50 